\title{
SISTEM LAYANAN KEPENDUDUKAN TERPADU DESA
}

\section{Indah Fitri Astuti}

\author{
Program Studi Ilmu Komputer, Fakultas Ilmu Komputer dan Teknologi Informasi, Universitas Mulawarman \\ Jalan Barong Tongkok Kampus Gunung Kelua Samarinda, Telp. (0541)741118, Kalimantan Timur \\ E-mail : indah@fkti.unmul.ac.id
}

\begin{abstract}
ABSTRAK
Banyaknya jenis layanan yang harus diselesaikan dan jumlah warga yang setiap hari datang ke kantor desa membuat kebutuhan akan suatu sistem layanan yang terkomputerisasi dan juga terpadu menjadi mendesak. Salah satu kantor desa yang mengalami hal ini adalah kantor desa Girimukti di Kabupaten Penajam Paser Utara yang harus melayani lebih dari empat puluh permintaan layanan dokumen kependudukan setiap harinya. Terbatasnya jumlah staf dan sumber daya menjadikan waktu layanan menjadi relatif lama yaitu sekitar tiga hari sampai dengan dua minggu. Sistem ini dibangun berbasis web dengan tujuan penggunaan yang lebih luas dalam hal waktu dan tidak terbatas di kantor saja. Pimpinan desa dapat memantau sistem ini dimanapun berada untuk ikut berpartisipasi dalam pemotongan waktu layanan, sedangkan staf desa dapat menjadi sumber daya manusia yang lebih melek teknologi dan bekerja dengan orientasi pada efisiensi dan efektifitas. Penelitian ini menghasilkan suatu sistem layanan berbasis web yang kemudian dimanfaatkan sebagai tulang punggung operasional dalam melayani warga.
\end{abstract}

Kata Kunci : kependudukan, layanan, desa, sistem berbasis web, dokumen.

\section{PENDAHULUAN}

Girimukti adalah sebuah desa yang berkembang dan terletak di posisi strategis yang merupakan jalan penghubung antara kabupaten dan kota (BalikpapanPaser) dan antar propinsi (Kalimantan Timur, Kalimantan Selatan) dengan populasi sekitar 6000 penduduk (Girimukti, 2013). kantor desa adalah tempat yang penting di mana berbagai layanan penyelesaian bagi warga desa diadakan. kantor desa Girimukti sebagai pusat tugas pemerintahan desa dan fungsi sehari-hari sebagai pelayanan administrasi warganya. Terbatasnya jumlah staf dan sumber daya membuat waktu pelayanan menjadi relatif lama, yaitu sekitar tiga hari untuk dua minggu. Hal ini membuat kebutuhan untuk sistem yang kuat dan terintegrasi dalam fasilitas kompak menjadi mendesak. pengambilan kesulitan data juga dialami oleh petugas karena data tersebut masih disimpan dalam bentuk yang tidak unik dan rapi.

Mekanisme manual yang digunakan oleh staf administrasi berkontribusi pada panjangnya waktu pelayanan. Petugas sudah menggunakan komputer dalam pekerjaannya tetapi masih menggunakan teknologi minimal yang adalah kata aplikasi pengolahan dan pemrosesan dokumen. teknologi pembaruan yang digunakan dalam membangun sistem baru dianggap mampu membantu kinerja staf administrasi kantor desa Girimukti. Teknologi komputer dapat digunakan untuk membantu mengatasi masalah ini. Salah satu cabang dari ilmu komputer adalah sebuah sistem informasi. Sistem informasi berbasis komputer telah diaplikasikan di banyak aspek dalam kehidupan masa kini, baik di kegiatan pribadi, keluarga, bisnis maupun pemerintahan, sehingga cabang ilmu ini juga handal digunakan dalam menjadi ujung tombak layanan sehari-hari kepada masyarakat desa.
Studi dilakukan di kantor desa dengan melibatkan staf, sekretaris desa dan kepala desa untuk mendapatkan daftar analisis kebutuhan aplikasi yang akan dibangun. Observasi, wawancara dan pengumpulan dokumen yang diperlukan juga dilaksanakan untuk mendukung pengembangan ini. Dasar analisis kebutuhan sistem adalah dengan mengurai jenis layanan apa saja yang disediakan oleh kantor desa Girimukti.

Jenis layanan yang diselenggarakan oleh kantor desa dianalisis dan kemudian dipecah menjadi setiap pekerjaan untuk kemudian menjadi modul fungsional dalam sistem informasi.

Permasalahan yang telah diuraikan sebelumnya dapat diselesaikan dengan sistem komputerisasi dengan mengintegrasikan semua fungsi dan kebutuhan administrasi warga. Tujuan dari penelitian ini adalah untuk mengembangkan layanan penyelesaian berbasis web sistem informasi yang terintegrasi ke desa dengan sistem manajemen tujuan pemerintahan desa Girimukti yang handal dan berteknologi tinggi yang dapat dimanfaatkan oleh pihak administratif desa dalam menjalankan operasional sehari-hari melayani penduduk dalam menerbitkan atau mendukung keperluan administrasi kependudukan.

\section{TINJAUAN PUSTAKA}

Berdasarkan tinjauan literatur dari sejumlah sumber, beberapa jenis penelitian yang membahas perihal kependudukan telah dilakukan. Salah satunya adalah penelitian oleh Endang Gustiawan (2013) dengan judul tingkat kabupaten Desain Sistem Informasi Population Data Sedayu Bantul Yogyakarta yang menghasilkan data yang masuk pelaporan populasi, meninggal, lahir dan pindah [2]. Kemudian penelitian oleh Danas Saputro (2011) 
dengan judul Analisis dan Desain Sistem Informasi di Desa Candi Binangun Penduduk Pakem Sleman, Yogyakarta [3]. Sementara Waspodo dumadi (2011) meneliti Desktop Desa Petir Rongkop Kecamatan berdasarkan Data Penduduk Sistem Informasi Manajemen Surakarta [4].

\subsection{Sistem Informasi}

Sistem informasi adalah suatu sistem dalam suatu organisasi mempertemukan kebutuhan pengolahan transaksi harian yang mendukung fungsi manajerial organisasi dalam kegiatan strategis untuk menyediakan pihak luar tertentu dengan laporanlaporan yang diperlukan [1]. Sistem informasi adalah suatu sistem yang melibatkan manajemen sumber daya manusia, data, proses/pekerjaan, dan hasil dalam bentuk informasi bagi pihak yang membutuhkan.

Komponen sistem informasi terdiri dari komponen yang saling berinteraksi membentuk satu kesatuan untuk mencapai tujuan mereka [1]. Komponen tersebut meliputi:

\subsubsection{Blok Masukan}

Blok masukan merupakan entri data atau masuk ke dalam sistem informasi. masukan ini termasuk metode dan media yang digunakan untuk menangkap data yang akan dimasukkan, yang dapat berupa dokumen dasar.

\subsubsection{Blok Model}

Blok model ini terdiri dari kombinasi prosedur, logika, dan model matematik yang akan memanipulasi data input dan data yang tersimpan di basis data dengan cara yag sudah ditentukan untuk menghasilkan keluaran yang diinginkan.

\subsubsection{Keluaran}

Blok Keluaran adalah hasil dari sistem informasi adalah keluaran yang merupakan informasi yang berkualitas dan dokumentasi yang berguna untuk semua pemakai sistem.

\subsubsection{Teknologi}

Blok teknologi merupakan tool box dalam sistem informasi, teknologi digunakan untuk menerima input, menjalankan model, menyimpan dan mengakses data, menghasilkan dan mengirimkan keluaran, dan membantu pengendalian dari sistem secara keseluruhan.

\subsubsection{Basis Data}

Blok basis data (database) merupakan kumpulan data yang saling berkaitan dan berhubungan satu dengan yang lain, tersimpan di perangkat keras komputer dan menggunakan perangkat lunak untuk memanipulasinya. Data perlu disimpan dalam basis data untuk keperluan penyediaan informasi lebih lanjut. Data di dalam basis data perlu diorganisasikan sedemikian rupa supaya informasi yang dihasilkan berkualitas. Organisasi basis data yang baik juga berguna untuk efisiensi kapasitas penyimpanannya. Basis data diakses atau dimanipulasi menggunakan perangkat lunak paket yang disebut DBMS (Database Management System).

\subsubsection{Blok Kendali}

Banyak hal yang dapat merusak sistem informasi, seperti bencana alam, api, temperatur, air, debu, kecurangan-kecurangan, kegagalan-kegagalan sistem itu sendiri, ketidakefisienan, sabotase dan lain sebagainya. Blok pengendalian perlu dirancang dan diterapkan untuk meyakinkan bahwa hal-hal yang dapat merusak sistem dapat dicegah ataupun bila terlanjur terjadi kesalahan-kesalahan dapat langsung cepat diatasi.

\subsection{Pemodelan Data}

Pemodelan data yang digunakan adalah Unified Modeling Language (UML) dengan dua diagram, yaitu:

\subsubsection{Use Case Diagram}

Pemodelan Use Case adalah sebuah pendekatan untuk menangkap kebutuhan pengguna. Sebuah use case adalah urutan interaksi antara pengguna dan sistem yang dipertimbangkan untuk mencapai suatu tujuan. Seorang pengguna memulai penggunaankasus dengan tujuan tertentu dalam pikiran, dan melengkapi penggunaan-kasus ketika layanan memenuhi bahwa tujuan tertentu. Sistem ini diperlakukan sebagai "kotak hitam" di mana interaksi dengan sistem yang dirasakan dari luar sistem. Skenario adalah sebuah contoh dari penggunaankasus, mewakili variasi tunggal kasus penggunaan.

\subsubsection{Activity Diagram}

Diagram aktivitas adalah jenis diagram alur dengan dukungan tambahan untuk perilaku paralel. Diagram aktivitas meliputi konsep-konsep perilaku baru. Cabang dan model penggabungan perilaku bersyarat dari diagram aktivitas. Sebuah cabang memiliki transisi masuk tunggal dan ganda, kondisional, transisi keluar. Aliran kontrol diarahkan ke salah satu transisi keluar tergantung pada kondisi baik. Sebuah penggabungan adalah node dalam diagram aktivitas di mana perilaku bersyarat berakhir. Setiap cabang di diagram aktivitas memiliki gabungan sesuai.

Fork dan model perilaku paralel dari sistem. Sebuah fork dalam diagram aktivitas memiliki transisi masuk tunggal dan beberapa transisi keluar menunjukkan perilaku paralel. Transisi yang masuk memicu transisi keluar paralel. Sebuah 'join' dalam diagram aktivitas mensinkronisasikan perilaku paralel dimulai pada fork. Sebuah 'join' mengetengahkan bahwa semua set paralel kegiatan (terlepas dari urutan) selesai sebelum aktivitas berikutnya dimulai. Ini adalah titik sinkronisasi dalam diagram. Setiap fork dalam diagram aktivitas memiliki yang sesuai bergabung di mana berakhir perilaku paralel [5]. 


\section{METODOLOGI}

Penelitian ini dilakukan di Desa Girimukti, Penajam Paser Utara, Kalimantan Timur dalam melakukan pengumpulan data, dan wawancara dengan Lurah, staf, dan warga [6]. Pengamatan juga dilakukan dalam rangka untuk mendapatkan pemahaman penuh pada persyaratan dan situasi. Proses pengkodean dikerjakan di Laboratorium Software Engineering Fakultas Ilmu Komputer dan Teknologi Informasi, Universitas Mulawarman. Tahap pengembangan sistem dalam penelitian menggunakan metode Waterfall yang terdiri dari lima tahap, yaitu:

\subsection{Analisis Kebutuhan}

Seluruh kebutuhan perangkat lunak harus bisa didapatkan dalam fase ini, termasuk didalamnya kegunaan perangkat lunak yang diharapkan pengguna dan batasan perangkat lunak. Informasi ini biasanya dapat diperoleh melalui wawancara, survei atau diskusi. Informasi tersebut dianalisis untuk mendapatkan dokumentasi kebutuhan pengguna untuk digunakan pada tahap selanjutnya.

\subsection{Desain Sistem}

Tahap ini dilakukan sebelum melakukan coding. Tahap ini bertujuan untuk memberikan gambaran apa yang seharusnya dikerjakan dan bagaimana tampilannya. Tahap ini membantu dalam menspesifikasikan kebutuhan perangkat keras dan sistem serta mendefinisikan arsitektur sistem secara keseluruhan.

\subsection{Implementasi}

Tahap ini adalah pemrograman. Pembuatan perangkat lunak dipecah menjadi modul-modul kecil yang nantinya akan digabungkan dalam tahap berikutnya. Selain itu dalam tahap ini juga dilakukan pemeriksaaan terhadap modul yang dibuat, apakah sudah memenuhi fungsi yang diinginkan atau belum.

3.4. Integrasi dan Pengujian

Tahap ini merupakan penggabungan modulmodul yang sudah dibuat dan dilakukan pengujian ini dilakukan untuk mengetahui apakah perangkat lunak yang dibuat telah sesuai dengan desainnya dan masih terdapat kesalahan atau tidak.

3.5. Operasi dan Pemeliharaan

Tahap ini merupakan tahap terakhir dalam model waterfall. Perangkat lunak yang sudah jadi dijalankan serta dilakukan pemeliharaan. Pemeliharaan termasuk dalam memperbaiki kesalahan yang tidak ditemukan pada langkah sebelumnya. Perbaikan implementasi unit sistem dan peningkatan jasa sistem sebagai kebutuhan baru. Kelebihan metode Waterfall adalah bahwa semua kebutuhan sistem dapat didefinisikan secara utuh, eksplisit, dan benar diawal proyek, sehingga perangkat lunak dapat berjalan dengan baik sesuai tujuannya tanpa kendala dan bug [1].

\section{HASIL DAN PEMBAHASAN}

\subsection{Perancangan Data}

Pemodelan data dirancang dengan menggunakan UML. Diagram awal UML adalah Use Case Diagram seperti disajikan pada gambar 1.

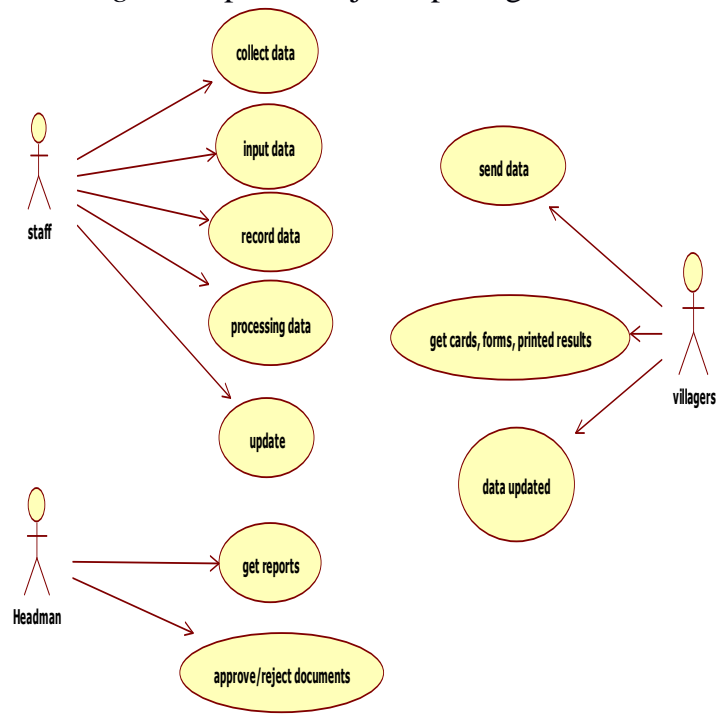

Gambar 1. Use Case Diagram Sistem Layanan Kependudukan Desa

Gambar 1 memaparkan apa saja kegiatan yang dapat dilakukan oleh tiga aktor dalam sistem ini yaitu kepala desa, staf kantor desa dan warga. Sebagai permulaan, staf akan input atau pencarian data penduduk desa kemudian masukan, catatan, pengolahan dan akhirnya memberikan penduduk desa dokumen yang dibutuhkan setelah dibubuhi persetujuan pimpinan.

Diagram kedua adalah Activity Diagram yang menjelaskan tentang urutan aktivitas sistem dengan menggunakan pendekatan sistem dan staf serta hubungan aktivitas antara keduanya. Diagram ini disajikan pada gambar 2 .

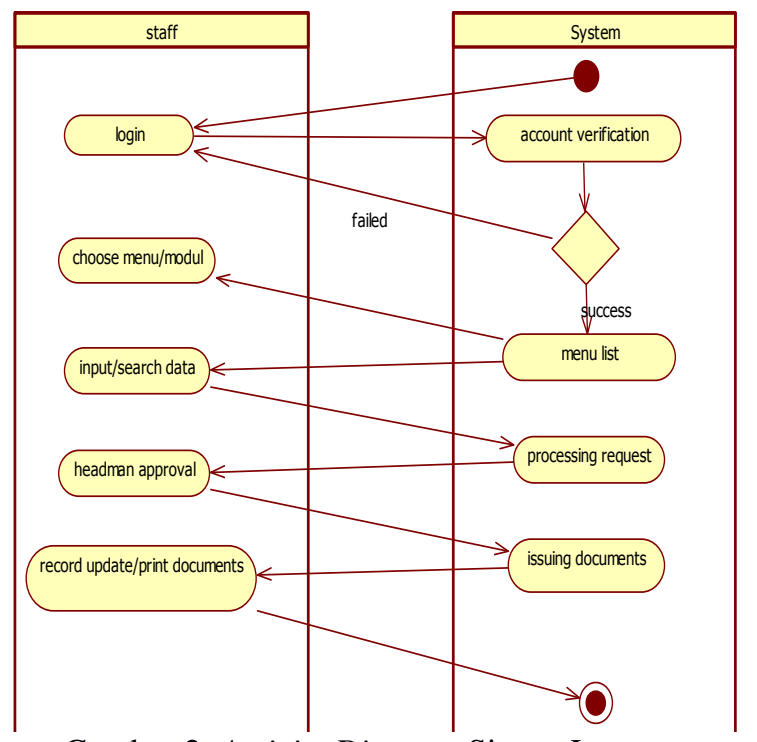

Gambar 2. Activity Diagram Sistem Layanan Kependudukan Desa 


\subsection{Implementasi}

Setelah pengkodean dan perancangan antarmuka pengguna dilakukan maka implementasi dapat dilaksanakan. Pengguna masuk ke sistem/aplikasi melalui sebuah form login terlebih dahulu dengan verifikasi username dan sandi (seperti disajikan pada gambar 3). Hal ini diatur agar tidak ada pengguna yang tidak berhak masuk ke sistem tersebut karena data yang ada di dalamnya bersifat rahasia.

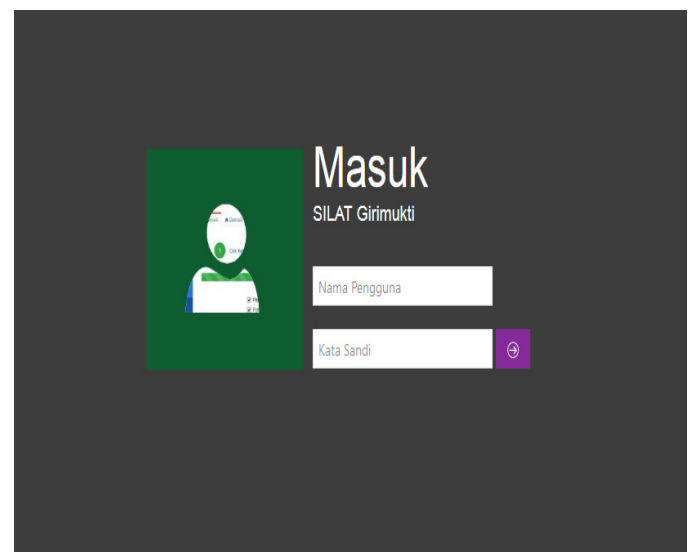

Gambar 3. Form Login

Sedangkan halaman awal/utama aplikasi ini disajikan pada gambar 4 .

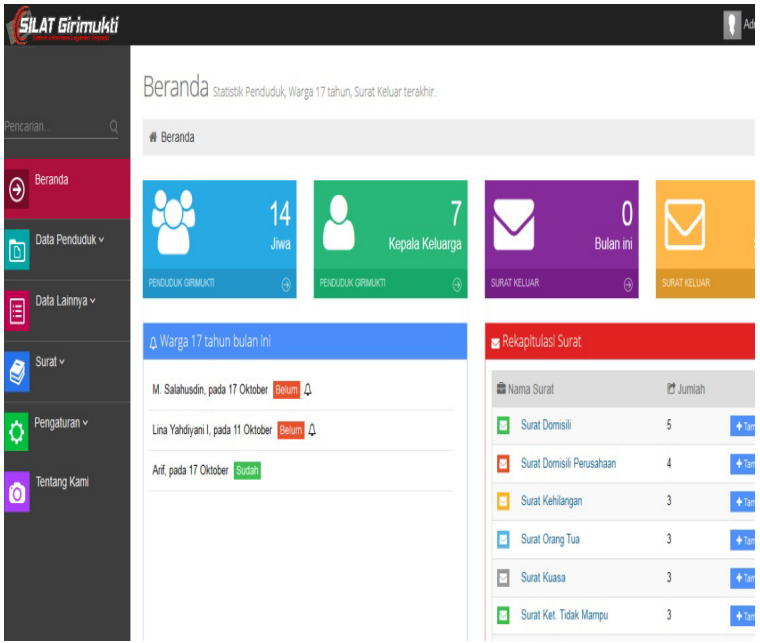

Gambar 4. Halaman Utama

Perbaruan data kependudukan bisa dilakukan pada formulir seperti pada gambar 5. Form ini memiliki dua tab, yaitu klasifikasi penduduk sudah memiliki kartu keluarga (KK) dengan yang tidak memiliki KK.

Warga yang tidak memiliki kartu keluarga akan dibuatkan kartu khusus sebagai pemukin musiman yang otomatis akan diterbitkan oleh desa selagi yang bersangkutan tinggal di desa tersebut. Sedangkan bagi warga yang memiliki kartu keluarga biasanya telah terekam datanya di basis data sistem sehingga penanganannya lebih mudah dan cepat.

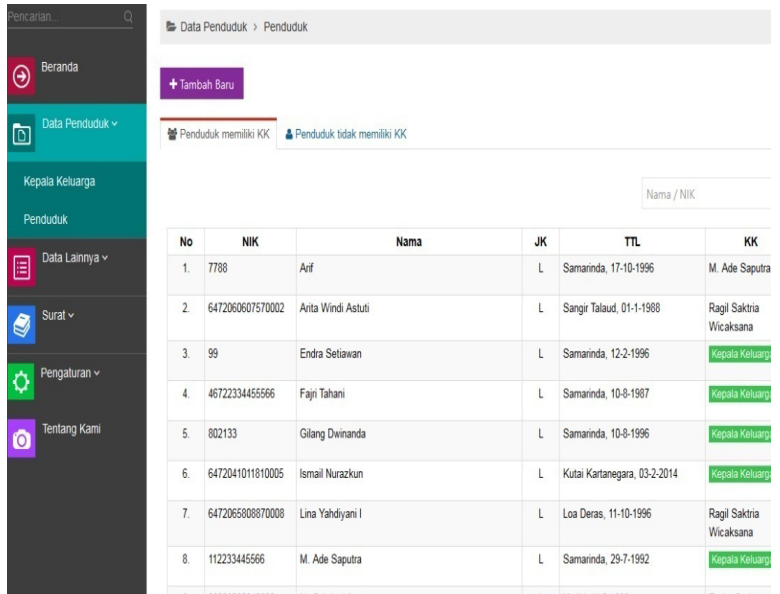

Salah surat yang dapat diterbitkan oleh desa dengan menggunakan sistem ini adalah surat domisili, seperti disajikan pada gambar 6 .

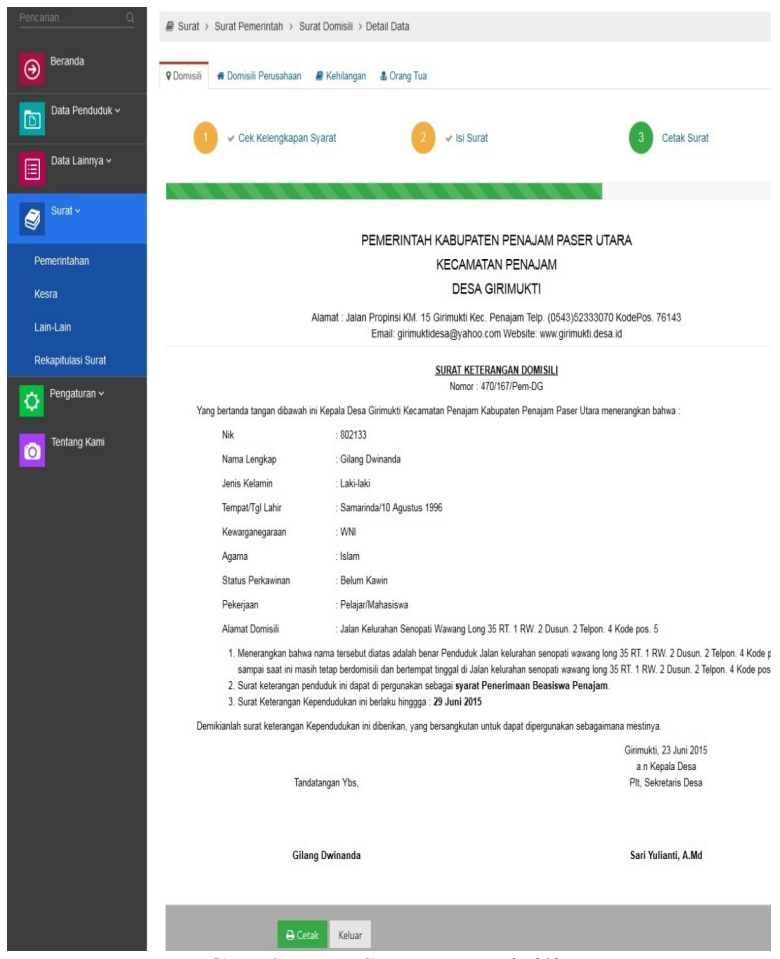

Gambar 6. Surat Domisili

Surat-surat lain yang dapat diterbitkan antara lain surat pengantar kelahiran, surat pengantar nikah, surat pengantar kartu tanda penduduk, surat keterangan tidak mampu, surat orang tua dan surat kehilangan. Warga dapat mengecek apakah keperluannya telah selesai atau belum diproses melalui tautan yang dapat diakses melalui internet.

\section{KESIMPULAN}

Berdasarkan penelitian yang telah dilaksanakan dapat ditarik kesimpulan bahwa telah dihasilkan sebuah sistem berbasis web yang dibangun untuk melayani warga dalam pembuatan surat-surat yang berhubungan dengan kependudukan secara terpadu melalui satu pintu. Para pihak yang berkepentingan seperti pimpinan desa, staf dan warga dapat 
mengakses sistem ini melalui internet berdasarkan hak guna masing-masing.

\section{DAFTAR PUSTAKA}

[1]. Jogiyanto H. M. 2010 Analisa Desain Sistem Informasi. Yogyakarta : ANDI.

[2]. Gustiawan E. 2013. Rancang Bangun Sistem Informasi Data Kependudukan tingkat Kecamatan Sedayu Bantul Yogyakarta. Yogyakarta : STMIK El Rahma.

[3]. Saputro D. 2011. Analisis dan Perancangan Sistem Informasi Kependudukan di Kelurahan Candi Binangun Pakem Sleman Yogyakarta. Skripsi. Yogyakarta : STMIK Amikom.

[4]. Dumadi W. 2011. Sistem Informasi Pengelolaan Data Penduduk berbasis Desktop di Desa Petir Kecamatan Rongkop Kota Surakarta. Skripsi. Surakarta: Universitas Muhammadiyah Surakarta.

[5]. Ram K. Elbaum S. 2002. Short UML Reference.

[6]. Girimukti 2013. Data Penduduk Desa Girimukti Kecamatan Penajam Kabupaten Penajam Paser Utara Provinsi Kalimantan Timur. 